\title{
Article
}

\section{Republican Reimaginings in Marlowe's Edward II}

\author{
Christopher Ivic (1)
}

check for updates

Citation: Ivic, Christopher. 2022. Republican Reimaginings in Marlowe's Edward II. Humanities 11: 23. https://doi.org/10.3390/ h11010023

Academic Editor: Sophie Mills

Received: 17 December 2021

Accepted: 26 January 2022

Published: 3 February 2022

Publisher's Note: MDPI stays neutral with regard to jurisdictional claims in published maps and institutional affiliations.

Copyright: (C) 2022 by the author. Licensee MDPI, Basel, Switzerland. This article is an open access article distributed under the terms and conditions of the Creative Commons Attribution (CC BY) license (https:// creativecommons.org/licenses/by/ $4.0 /)$.
English Literature, Bath Spa University, Bath BA2 9BN, UK; c.ivic@bathspa.ac.uk

\begin{abstract}
This essay explores the intersection of republican and nationalist ideas in Marlowe's Elizabethan history play Edward II. I read the play less in terms of recent dominant readings: that is, focussing on the same-sex relation between King Edward and his 'minion' Gaveston. Instead, I focus on the play's critique of Edward's authoritarian and arbitrary rule, a critique of monarchy informed by proto-republican ideology and a nascent nationalism. This essay also considers the play's archipelagic angles within the context of the play's initial inscription-Queen Elizabeth's two-kingdom, three-nation rule-as well as its Jacobean publications.
\end{abstract}

Keywords: Christopher Marlowe; England; Scotland; Edward II; nationhood; republicanism; elective monarchy

Richard Helgerson opens his magisterial Forms of Nationhood with a list of authors who represent a 'generation's contribution to the writing of England' (Helgerson 1992, p. 1). Noting that this collective project was not restricted to these eight men, Helgerson offers more names, one of which is Christopher Marlowe. Given that a chapter in Forms of Nationhood explores 'the new genre of the national history play' (Helgerson 1992, p. 245), it is surprising that Marlowe's Edward II, a key text among the nascent genre, receives no mention. Where might Helgerson have placed Marlowe's Edward II within the opposition that he posits between Shakespeare's and the Lord Chamberlain's Men's 'exclusively monarchic' (Helgerson 1992, p. 245) histories and the Henslowe playwrights' concern with the common people ${ }^{1}$ Edward II, Marlowe's sole single-authored play set in England (and Wales), went through four editions (1594, 1598, 1612, 1622). However popular the play was among late sixteenth- and early seventeenth-century readers, it is not strictly speaking a 'people's history', to use Helgerson's term for the history plays staged by the Henslowe companies (Helgerson 1992, p. 237). The play's action is dominated by a feuding royalty and nobility, fuelled mainly by the peers' animosity toward the King's 'upstart' favourites. The peers' animosity to Edward's abuse of power is motivated by an oppositional politics grounded in republican ideas and underpinned by a deep-rooted patriotism if not nationalism. ${ }^{2}$ Edward II, I argue, stages a republican drama of a beleaguered political nation.

I begin this essay with a reference to Helgerson's work because of its influence on readings of Edward II. Focussing on Marlowe's revisions to the chronicle sources' account of Edward II's reign, Joan Parks situates Marlowe firmly in the Shakespeare and Lord Chamberlain's Men camp: 'If we consider his revisions, first, within the context of national definition, we can see that Marlowe's omission of references to the larger realm and almost all mention of the citizens or "people" effectively excludes these actors from portrayals of the nation' (Parks 1999, p. 282). The 'people' are mentioned, however infrequently, and they appear on stage: in the form of the three Poor Men that Gaveston encounters at the play's opening, for instance, as well as in the form of Baldock, the Welsh soldier Rice ap Howell and the Mayor of Bristol. As the peers heighten their attack on Edward, the people emerge among the play's dissident voices. Witness, for example, Mortimer Junior's

The idle triumphs, masques, lascivious shows,

And prodigal gifts bestowed on Gaveston 
Have drawn thy treasure dry and made thee weak;

The murmuring commons overstretched hath. (Marlowe 2002, 2.2.156-9) ${ }^{3}$

These lines are representative of a number of references to public or common dissent in the play, and they echo similar criticism of King Edward in Holinshed's Chronicles: for example, 'so that the English nation began to grow in contempt by the infortunate gouernment of the prince' (Holinshed 1587, III, p. 342). ${ }^{4}$ Shortly after the reference to the 'murmuring commons', Mortimer Junior says to Edward 'Libels are cast against thee in the street; / Ballads and rhymes made of thy overthrow' (2.2.176-7), lines followed by Lancaster's 'The northern borderers, seeing their houses burnt, / Their wives and children slain, run up and down, / Cursing the name of thee and Gaveston' (2.2.178-80). Pembroke's pronouncement on Gaveston's banishment as 'good news to the common sort' (1.4.92) is another example of the public disapproval of Edward's reign, as is Lancaster's response after seizing the document that Edward has signed to seal Gaveston's banishment: 'Give it me. I'll have it published in the streets' (1.4.89). At various moments in the play, the attitudes of the commoners allow Marlowe's audience and readers to gauge the play's shifting political allegiances. This is made most explicit by the increasingly Machiavellian Mortimer Junior: 'The King must die, or Mortimer goes down. / The commons now begin to pity him' (5.4.12). But it is Edward, or Edward's reign, to whom the title of 'England's scourge' (3.3.38) is bestowed. In response to Edward's ordering of the deaths of Lancaster and WarwickWarwick's penultimate speech sees him denounce Edward as a 'Tyrant' (3.3.21)-Mortimer Junior wails 'England, unkind to thy nobility, / Groan for this grief' (3.3.31). ${ }^{5}$ Whilst his invocation of England could be read as conflating Edward and England, it reads more like an apostrophe to an England dissociated from its sovereign, a political body, moreover, to which the play's characters direct their allegiance and affection. In other words, the 'natural' love that the peers 'would' have for their sovereign is redirected 'to this our native land' (1.2.98-9, 2.3.1 my emphasis), an affection heightened, surely, by the London stage actor's use of deixis.

Although Parks does not cite Helgerson's work on the national history play, her analysis of Edward II owes much to his reading of Shakespeare's English histories as 'exclusively monarchic'. Marlowe, Parks concludes, 'presents a monarch-centered nation, driven by private force' (Parks 1999, p. 289). The phrase 'monarch-centered nation' fails to take into account the diminution of Edward's political (but not dramatic) centrality in the play. The history of a weak king surrounded by favourites supplied Marlowe with rich dramaturgical possibilities. The history of a weak king whose reign was marked by delegation and deposition also afforded Marlowe, whom Patrick Cheney labels 'the pioneer author in the writing of English republicanism' (Cheney 2006, p. 27), with rich political possibilities. Historically-Marlowe did not include this-when Edward II journeyed to France in 1308 for his marriage to Isabella, Piers Gaveston was made regent of England in Edward's absence, and later in the same year an exiled Gaveston was made lieutenant in Ireland. ${ }^{6}$ The play's concluding scenes are given over to Edward's deposition, Edward III's minority rule (at once an act of succession and election) and Mortimer Junior's Protectorship. In response to Edward's 'Am I a king and must be overruled?' (1.1.134), I argue that Edward II enacts a decentring of the monarch, if not the concept of monarchy itself. The result is a profoundly republican reimagining of the political nation.

\section{1. 'Is This the Love You Bear Your Sovereign?': Nationhood and Affect}

If, as I argue, Edward II does not present 'a monarch-centered nation', then what kind of political community does Marlowe's Edward II imagine? The answer to this question is far from simple. Complicating matters is the play's use of a variety of terms when referring to the early fourteenth-century England of Edward's troubled rule. 'England' occurs forty-two times in the play, ranking the play's uses of 'England' among the most of any early modern play. Terms substituted for 'England' include 'nation' and 'commonweal' (both used just once) ${ }^{7}$, 'state' (twice), 'kingdom' (three times), 'country' (nine times), 'land' 
(ten times) and, by far the most frequently employed term, 'realm' (twenty-five times). ${ }^{8}$ What do these various references-their denotations, connotations not to mention the cultural, ideological and political work they perform-suggest about the play's imagining of 'England'? That Edward II contains numerous references to 'realm' and just one to 'commonweal' could mean the play imagines a monarchical realm. According to Ralf Hertel, "[w]hereas "realm" denotes England as a territory belonging to its rulers, "commonwealth", or "common wealth" as it was frequently spelt, points towards a collective source of authority as opposed to a monarchical one' (Hertel 2014, pp. 10-11). Reflecting on the use of 'realm' in government documents during King Edward VI's minority, Liah Greenfeld argues that 'realm' acquired 'the meaning of a polity which is a collective enterprise, rather than the king's property' (Greenfeld 1992, p. 37). In Edward II, 'realm' is voiced by numerous characters, and whilst it can denote an England belonging to the monarch-for instance, Edward's 'my realm' (3.1.3) - it can also signify a communal territory. In order to understand nationality, nation-ness and nationalism properly, Benedict Anderson argues, 'we need to consider carefully how they have come into historical being' (Anderson 1991, p. 4); such consideration includes, of course, the language that members of a nation used to designate the polity. 'The barons', Lisa Hopkins notes, 'insistently deploy a ... discourse, centring on the words "realm" and "country"' (Hopkins 2010, p. 343). Indeed, Edward never uses the word 'country', and the peers never voice the word 'kingdom'. The play's sole use of the word 'commonweal' - Kent's 'Oh, miserable is that commonweal / Where lords keep courts and kings are locked in prison' (5.3.63) —attests to the risk of approaching this play with fixed definitions. Pace Hertel, Kent's use of 'commonweal' voices an anxiety about the power of a collective source of authority ('lords') at the expense of the royal prerogative.

Throughout most of the play, Marlowe, like Holinshed, presents Edward's rule unfavourably, especially as the King shares his royal authority and privilege with personal favourites: Gaveston, initially, and then Spenser Senior and, especially, Spenser Junior, both of whom are described in Holinshed's Chronicles as 'vnprofitable members in the common-wealth' (Holinshed 1587, III, p. 327). To Mortimer Junior's 'wilt [thou] fight it to the last, / And rather bathe thy sword in subjects' blood / Than banish that pernicious company' (3.2.26-8), Edward replies 'Rather than thus be braved, / Make England's civil towns huge heaps of stones, / And plows to go about our palace gates' (3.2.29-31)—not exactly music to an Elizabethan audience's ears. Edward's care for the self and disregard for England is most explicit in his response to the peers' deposition of Gaveston, which Edward attempts to divert by promising the peers social and political advancement:

My lord [Canterbury], you shall be chancellor of the realm,

Thou, Lancaster, high admiral of our fleet,

Young Mortimer and his uncle shall be earls,

And you, Lord Warwick, President of the North,

And thou [Pembroke] of Wales. (1.4.65-9)

These lines are immediately followed by Edward's

If this content you not,

Make several kingdoms of this monarchy

And share it equally amongst you all,

So I may have some nook or corner left

To frolic with my dearest Gaveston. (1.4.69-73)

Again and again, Edward's privileging of private desire-conveyed by the verb 'frolic' —over public duty undermines his rule. The King's willingness to fragment the kingdom threatens real (geographic) and imagined (conceptual) demarcations of the nation. The OED attributes to this passage the following meaning for 'nook or corner': 'the furthest, smallest, or most obscure parts or aspects' (OED n. Phrases), which captures Edward's desire for a private 
space for Gaveston and himself. Other possible meanings include 'A point of land running into the sea; a headland, a promontory' (4a), which anticipates Gaveston's exile to Ireland as well as Edward's failed attempt to escape to Ireland, his boat driven to shore in south Wales before his eventual capture. Edward's 'And share it equally amongst you all' is remarkable in that it anticipates forms of political organisation grounded in a sharing of power that, as we shall see, surface later in the play. The play's opening, 'Come, Gaveston, / And share the kingdom with thy dearest friend' (1.1.1-2), lines spoken by Gaveston but written by Edward, immediately point to a need to divest the weak and partisan monarch of power. To Edward's 'Was ever king thus overruled as I?', Lancaster deftly-that is, deferentially yet admonishingly - replies 'Learn then to rule us better, and the realm' (1.4.38-9), a stinging reply that marks Lancaster as both subject and citizen.

In her Nationalism: Five Roads to Modernity, Greenfeld argues that sixteenth-century England witnessed a shift from monarch-centred conceptualisations of England to conceptualisations of a political body ever conscious of its national identity, and central to her work are political terms key to an emergent England. 'In the period between 1500 and 1650', Greenfeld writes, 'several crucial concepts altered their meaning and came into general use. The concepts were "country," "commonwealth," "empire," and "nation." The changes in meaning were concentrated in the sixteenth century. The four words became understood as synonyms, acquiring the sense which, with slight alterations, they retained later, but which differed from their separate meanings before. They came to mean "the sovereign people of England"' (Greenfeld 1992, p. 31). One word to which Greenfeld lends particular focus is 'country', which she describes as 'one of the most evocative terms of the period', adding, 'it is clear from the context of numerous contemporary writings that in saying "my country," sixteenth-century Englishmen ... meant a great entity to which they owed supreme allegiance, patria, the nation' (Greenfeld 1992, p. 32). Perhaps Greenfeld fixes to these words meanings that are too rigid and too stable. Still, one way to understand better the political nation that the play imagines is to explore its various and shifting invocations of allegiance.

Just before Gaveston's return from Ireland, the peers lament the political costs of Edward's attachment to his 'minion'. 'Nothing but Gaveston', Mortimer Junior proclaims, adding 'You have matters of more weight to think upon; / The King of France sets foot in Normandy' (2.2.7-9), to which Edward flippantly replies 'A trifle. We'll expel him when we please' (2.2.10) — a line that comes back to haunt Edward when Isabella informs him later in the play that 'Lord Valois, our brother, King of France, / Because Your Highness hath been slack in homage, / Hath seized Normandy into his hands' (3.1.62-4). The peers then mock Edward's advancement of the 'upstart' Gaveston, to which an enraged Edward responds 'Is this the love you bear your sovereign?' (2.2.30). This question initiates the play's serious reflection on and interrogation of subjects' affection or loyalty.

During the play's depiction of the historical Tyneside battle, Edmund, Edward's brother, announces his shift of allegiance from Edward to the peers:

My lords, of love to this our native land

I come to join with you and leave the King,

And in your quarrel and the realm's behoof

Will be the first that shall adventure life. (2.3.1-4)

Edmund's declaration of his 'love' for 'this our native land' is a prime example of the play's patriotism or affective nationalism, especially as it is motivated by his commitment to the res publica. His use of 'realm' intersects with the sense that Greenfeld ascribes it: 'a polity which is a collective enterprise, rather than the king's property' (Greenfeld 1992, p. 37). Whereas 'kingdom' denotes a polity organised by political subjection, 'our native land' connotes a sense of belonging: one's place of birth, one's country, a national community. ${ }^{9}$ At various moments in the play, characters invoke 'country' and 'England', as opposed to divinity, in order to legitimate their political actions. After the peers have captured Gaveston, Warwick introduces a phrase that functions like a refrain in the play: 'it is our country's cause' 
(2.5.22). Upon seizing Gaveston, who is guarded by the earl of Pembroke's men, Warwick states 'it is my country's cause I follow' (2.6.10). Further instances include Kent's 'my country's cause' (4.1.3) - at this point Kent is siding with the peers-and Mortimer Junior's 'our country's cause' (4.4.18). When Queen Isabella declares 'Care of my country called me to this war' (4.6.65), her care for England, combined with an opposition to Edward, serves to naturalise the French Queen. Mortimer Junior's response to Isabella-'Your king hath wronged your country' (4.6.67) — reveals the intersection of political opposition and national belonging as well as a collective and affective sense of nationhood. Edward's references to 'my kingdom', 'my land' and 'my realm' are far outnumbered by his numerous references to 'my crown', but they all bear witness to an individual and possessive claim grounded in a sense of dominion rather than national belonging or connection. Not surprisingly, when a disempowered Edward reflects on his reign, he cites his 'rule and empery' (4.7.14).

\section{2. 'Chased from England's Bounds': Displacing the Monarch}

The historical 'England' that Edward II, which was entered into the Stationers' Register on 6 July 1593, brings to the stage is, of course, informed by the political culture that conditioned Marlowe's writing, ranging from such diverse ideas as the 'mixed monarchy' outlined by Thomas Smith in De Republica Anglorum: the Maner of Gouernement or Policie of the Realme of England (1581/3), the seditious 'Leicester's Commonwealth' (scribal publications) and Catholic resistance theories motivated by (publicly banned) discussions of the succession question in the latter half of Queen Elizabeth's reign, Robert Person's Conference about the Next Succession to the Crowne (Antwerp 1595) being the key text. ${ }^{10}$ In response to New Historicism's fetishising of power, as evinced in Helgerson's reading of Shakespeare's history plays, literary historians of the early modern stage are rereading select plays as the products of playwrights who were, to paraphrase Patrick Collinson, citizens concealed within the status of subjects (Collinson 1990, p. 24). In other words, once-ubiquitous deference to authority has given way to oppositional discourses, including republican ideas. In reference to Shakespeare's first tetralogy, to which Marlowe, it has recently been argued, contributed, Andrew Hadfield writes, '[t]his major collaborative project needs to be read in terms of the prevailing notion of a "monarchical republic"' (Hadfield 2005, p. 149). ${ }^{11}$ Cheney detects in Marlowe's literary republicanism not only caution against but also resistance to monarchical absolutism, and he designates Edward II 'an especially sturdy example of Marlowe's republican authorship toward the end of his literary career' (Cheney 2009, p. 148). ${ }^{12}$ 'Republicanism', simply put, 'challenged the arbitrary rights of kings in the name of the common good' (Calhoun 1997, p. 70). When Edward asks 'But tell me, must I now resign my crown, / To make usurping Mortimer a king?', Winchester's response is telling: 'Your Grace mistakes; it is for England's good, / And princely Edward's right we crave the crown' (5.1.38-9). Winchester's correction shifts the focus from the dynastic realm to the res publica.

Central to 'republican authorship' in late sixteenth-century England was the return to and appropriation of ancient Roman texts by writers such as Cicero, Livy and Lucan, whether, for instance, in the form of translation or performed history. ${ }^{13}$ Edward II returns not to ancient Rome but medieval England, yet the play's allusions to the Roman Republic are significant: for example, when Gaveston compares himself to 'Caesar riding in the Roman street' (1.1.172) and when, later in the play, Rice ap Howell refers to Spencer Senior as 'this traitor to the state', comparing him to 'the lawless Catiline of Rome' $(4.6 .49,51)$. Not unlike other Elizabethan texts with republican-inflected ideas, Edward II occupies a safe historical vantage point so as to fend off potential charges of commenting dangerously on the present. 'Republicanism', Craig Calhoun notes, 'turned crucially on the notion of the public, and granted a powerful role to critical public discourse among members of a political community' (Calhoun 1997, pp. 70-71). Whilst this quotation calls to mind, say, John Milton's England, the place of the early modern stage in shaping public discourse should not be underestimated. The past to which Marlowe returns is, of course, significant within the context of Elizabethan political culture. Under the historical King Edward II, 
'England was being inevitably turned into a limited monarchy by the outcry of an united baronage against a weak and fickle ruler' (Fryde 1979, p. 3). In the play, Edward's reign is restricted if not contested by an oppositional nobility and a legitimating Parliament. Nowhere is this more evident than in the play's investment in the concept of elective monarchy. 14

If, as critics suggest, Marlowe's prime source for the play was Holinshed's Chronicles, then what might Marlowe have gleaned from this text's account of King Edward II's life? On the transition from King Edward II to his son King Edward III, Holinshed has this to say: 'And so thervpon the nine and twentith day of Ianuarie in session of parlement then at Westminster assembled, was the third king Edward, sonne to king Edward the second, chosen and elected king of England, by the authoritie of the same parlement, first (as before is said) confirmed by his fathers resignation' (Holinshed 1587, III, p. 318). Marlowe appropriates and intensifies the Chronicles' language of election. Edward's first entrance in the play is prefaced by Gaveston's 'Here comes the King and the nobles / From the Parliament' (1.1.71-2), which not only establishes the play's political drama but also foregrounds the legitimating power of 'the Parliament'. Republican strains surface again and again in the play. In the midst of a scene concerning Gaveston's exile, Mortimer Junior says to the Archbishop of Canterbury about Edward 'Curse him if he refuse, and then may we / Depose him and elect another king' (1.4.54-5). The play posits a mixed polity in that Edward's attempt to consolidate power is met by fierce opposition from the nobles, who emerge as key political players. Of course, Edward is not the only figure in the play looking to consolidate and abuse his power. Mortimer Junior's declaration 'I am Protector now' is followed by his 'The Queen and Mortimer / Shall rule the realm, the King, and none rule us (5.4.64-6), lines spoken at a moment when the play invites its audience and/or readers to view this 'Protector' as a threat to the realm. Sensing her and Mortimer's fall, Isabella says of her son 'Into the council chamber he is gone / To crave the aid and succor of his peers' (5.6.20-1). We see little of Edward III as king, but what we do see is a child monarch who earnestly seeks his peers' counsel. Marlowe's use of 'crave' here is significant in that the verb, at the time of the play's composition, had lost its earlier meaning - 'To demand (a thing), to ask with authority, or by right' (OED v.1a)—rendering Edward's rule not unlike the 'mixed monarchy' of his Tudor namesake.

Edward II's political investment in a mixed polity is captured forcefully in the play's use of the word 'peer'. The aforementioned reference to King Edward III among 'his peers' could, of course, be read, on one hand, as a term for those below him or, on the other, as a synonym for his equals. The specific setting of the 'council chamber', I would argue, suggests the latter. When Mortimer Junior refers to himself and his fellow nobles as those 'that be [Edward's] peers' (1.2.42), he does so fully aware that 'peers' signifies members of the hereditary nobility as well as, and especially, Edward's equals, a point reinforced by Mortimer Junior's 'We will not thus be faced and overpeered' (1.4.19). Warwick's 'Let [Edward] know his peers' (1.4.23) sounds very much like 'let Edward know his equals'. Moreover, Parliament figures centrally in the play. In the wake of Edward's defeat at Bristol, Kent demands of Queen Isabella 'How will you deal with Edward after his fall?' (4.6.31), Mortimer Junior's interjection, however self-serving, points to a powerful Parliament: "Tis not in her controlment, nor in ours, / But as the realm and Parliament shall please' (4.6.35-6). Edward evokes elective monarchy with contempt-he dismissively refers to Mortimer Junior as a 'new-elected king' (5.1.78) ${ }^{15}$ — but the play as a whole takes a very different approach. ${ }^{16}$ In response to Trussel's 'the Parliament must have present news' (5.1.84), the stage directions read 'The King rageth', and in his rage Edward declares to Leicester and Winchester, who have come to collect the crown and bring it to London, 'Elect, conspire, install, do what you will' (5.1.88). ${ }^{17}$ Earlier in this scene, Edward broodingly reflects on his political disempowerment:

But what are kings, when regiment is gone,

But perfect shadows in a sunshine day? 
My nobles rule; I bear the name of king,

I wear the crown but am controlled by them. (5.1.26-9)

Did Marlowe intend for his Elizabethan audience and readers to receive Edward's shadow king speech sympathetically, or did he offer up these lines as a stinging interrogative that cuts through 'regiment', defined by the $O E D$ as 'royal authority' (n.1.a) but also '[t]he office or function of ruler' (n.2.a)? ${ }^{18}$ Once captured, Edward is subject to various forms of degradation and ultimately cruelly tortured. Emily Bartels describes Edward II at the play's close as '[d]isempowered and displaced', adding that he 'is able to write himself into the position of political and sexual victim'. Acknowledging that Edward's 'complicity in the crisis of power is not erased', Bartels argues that it is softened and our sympathies toward him are encouraged' (Bartels 1993, p. 166). This history play is, of course, a tragedy, and Edward's words to Lightborn 'I see my tragedy written in thy brows' (5.5.73) introduce the pathos underpinning the staging of Edward's violent death. The play's title as it appears on the 1594 quarto-form octavo, which was printed after Marlowe's death, ascribes 'the tragicall fall' to Mortimer Junior: The troublesome raigne and lamentable death of Edward the second, King of England: with the tragicall fall of proud Mortimer. When Isabella proclaims 'Now, Mortimer, begins our tragedy' (5.6.23), she does so immediately after having informed Mortimer Junior of King Edward III's desire to seek revenge on her and Mortimer for having ordered his father's murder. If we shift the focus from 'our sympathies' to Marlowe's 'republican authorship', then Edward's disempowerment and displacement take on significant meaning. Through much of the play, the King is on the move; his movement eventually takes him outside of England into Wales. Kent describes Edward, who has just attempted to flee to Ireland, as 'chased from England's bounds' (4.6.62). Kent speaks this line in Bristol, which seems to mark a national boundary line, separating England from Wales. Reinforcing Edward's political displacement from 'the office or function of ruler', therefore, is his geographical displacement.

\section{3. 'That Peevish Frenchman': Un-English Gaveston}

Edward II's handling of nationhood has received nothing near the amount of critical scrutiny afforded Shakespeare's history plays. ${ }^{19}$ Readings of nationhood in Edward II have centred on the same-sex relationship between King Edward and his favourite, Gaveston. ${ }^{20}$ 'In Edward II', Stephen O'Neill argues, 'the Shakespearean drama of the nation, that broad concern with the condition of England, is overshadowed by a Marlovian drama of desire as the play focuses on the relationship between the king and his favourite, Gaveston' (O'Neill 1999 , p. 90). Given Gaveston's death before the play's midway point, is the 'drama of the nation' overshadowed by a 'drama of desire'? Surely Edward II stages a drama of the nation, and, surely, Gaveston plays a crucial role in the national drama.

Critics have noted that King Edward's opponents voice resistance less to Edward's and Gaveston's erotic relationship than to the social advancement of 'his old mate' (Holinshed 1587, III, p. 318). ${ }^{21}$ According to Curtis Perry, 'the discourse of corrupt favoritism is the period's most important unofficial vehicle for exploring constitutional unease concerning the nature and limits of personal monarchy within the balanced English constitution' (Perry 2006, p. 1). Following Holinshed, Marlowe has Edward promote Gaveston immediately upon his return to England from banishment:

I here create thee Lord High Chamberlain,

Chief Secretary to the state and me,

Earl of Cornwall, King and Lord of Man. (1.1.153-5)

Throughout the play's opening scenes, the peers rail against and ridicule Gaveston's newly acquired titles. Upon learning of Gaveston's advancement, the peers-Warwick, Lancaster, Mortimer Senior and Junior-term him 'base', 'slave', 'peasant', 'upstart' and, again and again, 'minion'. Lancaster's 'that base and obscure Gaveston' (1.1.100) sets the tone for the peers' scornful dismissal of 'the new earl', 'the ignoble vassal' $(1.4 .11,1.4 .16)$. 
However, the play adds a further layer of insults, ones absent from the chronicle sources, that target Gaveston's foreignness.

The historical Piers Gaveston was the son of Arnaud de Gabaston, a Gascon knight, and his wife, Claramonde de Marsan. The first reference to Gaveston in English military records is in 1297, when he served King Edward I in Flanders; he served in Edward's army in Scotland in 1300, alongside his father and brother, and on other occasions. Not long after entering the future Edward II's household, Gaveston received the first of his three exiles from England. Upon returning to England after his first exile, Gaveston was immediately created Earl of Cornwall by Edward II. Gaveston's position as royal favourite is evident in his position as regent during Edward's absence for the purpose of marrying Isabella of France. Gaveston's second exile saw him eventually serve as the King's lieutenant in Ireland, a prelude, perhaps, to his appointment as Edward's lieutenant in Scotland in 1311 before meeting his death at the hands of earls of Warwick, Lancaster, and Hereford in $1312 .^{22}$

In Holinshed's Chronicles, the account of the historical King Edward's reign opens with Gaveston's injurious influence on the king: 'for the vsing the said Peers [Gaveston] as a procurer of his disordered dooings, [Edward] began to haue his nobles in no regard, to set nothing by his instructions, and to take small heed vnto the goode gouernment of the commonwealth' (Holinshed 1587, III, p. 318). ${ }^{23}$ In Marlowe's play, the peers' diatribes against 'ambitious' (1.2.31) Gaveston similarly centre on the threat that he poses to 'the pliant king' (1.1.52) and, especially, the res publica. Mortimer Junior's prediction that Gaveston 'Will be the ruin of the realm' (1.2.32) is echoed by Edmund when he says to Edward 'I see your love to Gaveston / Will be the ruin of the realm and you' (2.2.207-08). Although Tudor chronicles figure Gaveston as a corrupter of King Edward II and, in turn, a threat to the realm, they do not cite his non-Englishness as a cause of, or among the causes of, his harmful presence in Edward's court. In fact, Tudor chronicles make little of Gaveston's non-Englishness. In Holinshed's account of Edward I's reign, Gaveston is described as 'an esquire of Gascoine' (Holinshed 1587, III, p. 313). The chronicler John Stow describes 'Pierce of Gauaston [as] a straunger borne' (Stow 1580, p. 326). Whilst the hostility that the peers direct at Gaveston is grounded in early modern notions of fixed social hierarchies and motivated by their objection to Edward and Gaveston's erotic relationship, it is reinforced by a xenophobic un-Englishing of Gaveston. Befitting his desire for 'Italian masques' (1.1.54), not to mention his 'short Italian hooded cloak' and 'Tuscan cap' (1.4.1213), Gaveston twice speaks Italian - 'Tanti' (1.1.22), 'malgrado'(2.5.5)—in between which he manages a 'Mort Dieu!' (1.1.89). Gaveston describes himself as having 'c[o]me lately out of France' (1.1.43), and Mortimer Junior labels him 'that peevish Frenchman' (1.2.7) and 'inveigling Frenchman' (1.2.57). The taunts directed at Queen Isabella, King Edward's French wife, it should be noted, never really take on a similar national component. ${ }^{24}$ When the Queen addresses her 'countrymen' $(4.4 .1,6)$ - the play's only two utterances of this word-'England's queen' (4.4.23) directs her speech not to her French countrymen but rather to her fellow English countrymen. When Mortimer Junior says to the Queen 'Your king hath wronged your country' (4.6.67), the country to which he refers is England.

As Lisa Hopkins notes, the peers' 'animus against Gaveston is [partly] that they see him as a stranger to the land to which they themselves avow such strong attachment' (Hopkins 2010, p. 342). Gaveston, according to O'Neill, 'is imagined as a catalyst for the emasculation of the king and the contamination of England' (O'Neill 1999, p. 92) ${ }^{25}$ On 'the lexicon of epithets' that the peers use for Gaveston, O'Neill remarks 'these evince ... the desire among the barons for a pure, homogeneous England that requires Gaveston's absence; and, since Ireland is the location of his absence, it is as if it becomes a repository of impure, alien elements' (O'Neill 1999, p. 91). Whilst the play marks Gaveston as a 'stranger', as 'alien', it is important not to overlook the ways in which he incites the play's rhetoric of nationhood. In the play's opening speech, Gaveston introduces key words in the play's political lexicon when he references 'the kingdom' (1.1.2), when he terms himself 'the favorite of a king' (1.1.5) and when he speaks dismissively of 'the lordly peers' (1.1.18) 
and 'the multitude' (1.1.20). ${ }^{26}$ In the opening scene, the play's dominant political term, 'the realm', is invoked in reference to Gaveston, and, significantly, these two early voicings of 'the realm' signify Gaveston's exclusion from it. Firstly, we have Mortimer Junior's address to King Edward:

Mine uncle here, this earl, and I myself

Were sworn to your father at his death

That [Gaveston] should ne'er return into the realm. (1.1.81-3)

These lines are soon followed by Lancaster's

Four earldoms have I besides Lancaster-

Derby, Salisbury, Lincoln, Leicester.

These will I sell to give my soldiers pay

Ere Gaveston shall stay within the realm. (1.1.101-04)

Georgia Brown argues that 'Edward II contributes to sixteenth-century debates about the nature of history and English identity, and expresses anxiety about what is being excluded from the definition of Englishness' (Brown 2002, p. 166). Foreign Gaveston is very much excluded from the play's affective rhetoric of nationhood. As mentioned, the word 'England' is spoken forty-two times in the play, but never by Gaveston. His voicing of 'kingdom' (1.12) and 'land' (1.4.107) mark the only instances in which he uses such political termsdescribing the former as 'his voicing' is problematic, for he is reading from a letter written by Edward. Gaveston's 'Were I a king - ' is cut off mid-sentence by Mortimer Junior, who retorts 'villain, wherefore talks thou of a king' (1.4.27-8).

If Gaveston's non-Englishness marks him out in the play, so too does his lack of attachment to England. The play opens with Gaveston having returned to England from France, and although he describes himself as 'exiled', he reveals no connection to the place from which he has been absent:

The sight of London to my exiled eyes

Is as Elysium to a new-come soul-

Not that I love the city or the men,

But that it harbors him I hold so dear,

The King, upon whose bosom let me die. (1.1.10-14)

Gaveston harbours no love for England or for Englishmen. When Gaveston learns that he is 'banished and must fly the land' (1.4.107), he says to Edward 'To go from hence grieves not Poor Gaveston, / But to forsake you' (1.4.119-20). Unlike the banished Mowbray in Shakespeare's Richard II, Gaveston expresses no connection to the 'land'; he privileges person over place. Gaveston's banishment is sanctioned by Canterbury, who, as 'legate to the Pope', demands of Edward 'On your allegiance to the see of Rome, / Subscribe as we have done to his exile' (1.4.51-3). Having done so, Edward then delivers the following soliloquy:

Why should a king be subject to a priest?

Proud Rome, that hatchest such imperial grooms,

For these thy superstitious taper lights,

Wherewith thy anti-Christian churches blaze,

I'll fire thy crazed buildings, and enforce

The papal towers to kiss the lowly ground.

With slaughtered priests may Tiber's channel swell

And banks raised higher with their sepulchres!

As for the peers that back the clergy thus,

If I be king, not one of them shall live. (1.4.96-105) 
Brown describes these lines as 'the play's most tub-thumping piece of nationalism'. 'This', she adds, 'is the stuff of Reformation nationalism' (Brown 2002, p. 182). However, as a speech with no on-stage audience, it falls on deaf ears. Edward's use of 'I' rather than the royal 'we' heightens the personal rather than public nature of his diatribe as does his hyperbolic threat to kill the peers. Immediately after this speech, Edward says to the banished Gaveston 'Be governor of Ireland in my stead, / And there abide till fortune call thee home' (1.4.125-6). It is to this wider archipelagic context that I now wish to turn.

\section{4. 'Great Edward Longshanks' Issue': England Beleaguered}

Holinshed's Chronicles' account of Edward II opens with his Welsh birth: 'Edward, the second of that name, the sonne of Edward the first, borne at Carnarvan [Caernarfon] in Wales' (Holinshed 1587, III, p. 318). In 1301, at the age of sixteen, Edward became the first son of an English monarch to acquire the title Prince of Wales. In this same year, King Edward II 'is recorded as having acquired a copy of a book 'de gestis regum Anglie', probably Geoffrey of Monmouth's Historia regum Britanniae, a work which was appropriate to his new status in Wales but also a reminder of the English crown's claims to supremacy over the entire island of Britain' (ODNB, 'Edward II [Edward of Caernarfon]'). When a young King Edward III is crowned near the play's close, Canterbury proclaims 'Long live King Edward, by the grace of God / King of England and Lord of Ireland' (5.4.73-4), a title that mirrors his father's. In other words, Edward II inherited from his father a potential British and Irish, or archipelagic, rule, for he was King of England and Lord of Ireland; Wales, moreover, was subject to English control. According to R. R. Davies, 'never had the physical presence of English power, be it in the person of the king himself or that of his appointed representatives, or in mighty castles such as Harlech and Beaumaris in Wales and Roscommon and Ballymote in the west of Ireland, been so ubiquitously and awesomely present in the outer zones of the British Isles as in the last fifteen years or so of Edward I's reign' (Davies 2000, p. 26). This narrative of Edward I would have been available to Marlowe through Tudor chronicles, such as Holinshed's, that memorialise Edward I as an archipelagic monarch: that is, an English king who nearly became the first king of Britain and lord of Ireland:

But now to conclude with this noble prince king Edward the first, he was sure not onelie valiant but also politike, labouring to bring this diuided Ile, into one entier monarchie, which he went verie neere to haue atchiued, for whereas he was fullie bent to make a conquest of Scotland, in like case as he had alreadie doone of Wales, if he had liued any longer time to haue dispatched Robert le Bruce, that onelie stood in his waie, it was verie likelie that he should haue found none other to haue raised banner against him about the quarrell or title to the claime of that realme. (Holinshed 1587, III, p. 317)

Edward II registers a desire to 'bring this diuided Ile, into one entier monarchie'. Both Edward and Isabella refer to 'this isle' $(1.4 .49 ; 2.4 .17)$, and although both references are geographical they intimate possession of, if not dominion over, 'the isle'. This sense of Edward's island-rule also manifests itself in the play's sole reference to Great Britain: namely, the King's 'the proudest peer of Brittany' (2.2.42), which David Bevington glosses as 'Great Britain'. If Edward's 'Brittany' ('Britanie' in the 1594 printed text ${ }^{27}$ ) is not a reference to Brittany, then to what does it refer? 'Britanie' could be read as an Anglocentric conflation of Edward's Anglo-Welsh (and Irish?) rule or, and I think this is the likelier reading, as assuming English rule of the entire island of Britain.

Whilst Spencer Junior's reference to King Edward II as 'Great Edward Longshanks' issue' (3.1.12) designates Edward the son of King Edward I, it also evokes the memory of 'Longshanks' as 'The Hammer of the Scots'. Longshanks' military and political exemplarity, however, functions in the play to underscore his son's failures as a king. Holinshed's narrative of Edward II's reign is very much an archipelagic history, for much of it focusses on Ireland, Wales and, especially, Scotland, particularly in terms of war. Dominating the narrative is a sense of loss: 'In this meane time the Scots now that the truce was ended, 
entring with a strong power into England, destroied all countrie to Newcastell vpon Tine with fire and sword. The Welshmen with their capteine Griffin Loitis tooke the castles of Mole, Chirke, and Olono' (Holinshed 1587, III, p. 329). The history of Edward I is a narrative of a conquering, subjugating England; the history of Edward II is a history of an England beleaguered by hostile neighbours.

For Goran Stanivukovic and Adrian Goodwin, 'Marlowe contemporises the fourteenthcentury history of King Edward II by intersecting it with the relationship between England and Ireland in the sixteenth century' (Stanivukovic and Goodwin 2017, p. 382). Marlowe wrote Edward II within the larger geopolitical context of Queen Elizabeth's three-nation (England, Ireland, Wales) and two-kingdom (England, Ireland) rule, with more than a 'glance' at Scotland, whose, monarch, King James VI, was the leading contender in the 1590s to succeed Elizabeth. ${ }^{28}$ Situating the play within a larger archipelagic context, I want to suggest, affords a better understanding of its inscription of nationhood.

Less than forty lines into the play, Gaveston encounters a soldier 'that hath served against the Scot' (1.1.33). ${ }^{29}$ Less than one hundred lines later, Mortimer Senior warns Edward 'Wilshire hath men enough to save our heads (1.1.126), and it has been suggested that 'Wilshire' is a 'compositor's misreading, or misunderstanding, of some form of "Welshry" (Gill 1980, p. 159), which makes sense given that the historical Roger Mortimer, first Lord Mortimer of Chirk, served as justice over the entire principality of Wales. The play's first reference to Ireland comes in the form of Edward's 'Be governor of Ireland in my stead (1.4.125), spoken to Gaveston in the wake of his banishment. The play's archipelagic context surfaces in act 1, scene 4, where Edward, after learning of Gaveston's repeal, elevates the Earl of Pembroke, makes Mortimer Junior 'Lord Marshall of the realm' (1.4.355), makes 'Lord Mortimer of Chirke' general of the 'levied troops / That now are ready to assail the Scots' $(1.4 .358,361-2)$, and sends a warrant for Gaveston's return from Ireland. At this moment in the play, 'England' (1.4.357) and 'the King of England' (1.4.365) are figured as 'quiet', 'safe' (1.4.357) and 'strong' (1.4.365), a situation, as Isabella observes, dependent on Edward 'Having the love of his renowned peers' (1.4.366). In other words, the peers' 'love' bolsters not just Edward's English but also his archipelagic rule, which in turn safeguards England. Act 1 concludes with Mortimer Senior's 'I must to Scotland', which, on one hand, looks forward to an extension of English archipelagic dominion but, on the other, provokes a troubled cultural memory, for the play's audience and readers would have been all too familiar with the heavy defeat the English received at the hands of the Scots during Edward II's reign.

Marlowe follows Holinshed in presenting Edward's rule as a failure geopolitically. This is especially true of the play's references to the Battle of Bannockburn (1314). Hopkins suggests that the play's 'stress on Edward's defeat at Bannockburn ... may well have been flattering to James of Scotland, to whom Marlowe might perhaps have been looking as a potential future patron' (Hopkins 2010, pp. 336-37). Perhaps it makes more sense to think of the play's invocations of Scotland in relation to the Elizabethan succession crisis, which no doubt took on more force for readers of the 1598 quarto of the play. Elizabethan discourse on the succession, especially as it concerned King James VI, was attended by uncertainty about new-figured relations between England and Scotland. From the vantage point of the 1590s, the accession of a Scottish monarch to England's throne could result in the first historical instance of a foreign monarch extending their rule over four nations (England, Ireland, Scotland, Wales) and three kingdoms (England, Ireland, Scotland). The play's Anglo-Scottish violence, therefore, can be read as reflecting public concerns about the succession and about threats to England's national sovereignty.

According to Robert Crawford, the historical King Edward II commissioned a poet to accompany his army to Scotland in 1314 in order to record in the form of a Latin poem England's certain victory over Scotland. 'This poem', Crawford writes, 'would enhance Edward's prestige, making clear that the might of one of Europe's great monarchies had put paid to Scotland's tenacious but absurd claims to independence' (Crawford 2014, p. 20). Bannockburn did nothing to enhance Edward's prestige. Holinshed describes how Edward 
with a mightie armie brauelie furnished, and gorgiouslie apparelled, more seemelie for a triumph, than meet to incounter with the cruell enimie in the field, entred Scotland, in purpose speciallie to rescue the castell of Sterling, as then besieged by the Scotishmen. But at his approching neere to the same, Robert Bruce was readie with his power to giue him battell. In the which king Edward nothing doubtfull of losse, had so vnwiselie ordered his people, and confounded their ranks, that euen at the first ioining, they were not onelie beaten downe and ouerthrowne, by those that coped with them at hand, but also were wounded with shot a farre off, by those their enimies which stood behind to succour their fellowes when need required, so that in the end the Englishmen fled to saue their liues, and were chased and slaine by the Scots in great number. (Holinshed 1587, III, p. 322)

Marlowe clearly has this passage in mind when he has Mortimer Junior say

When wert thou in the field with banner spread

But once? And then thy soldiers marched like players,

With garish robes, not armor; and thyself,

Bedaubed with gold, rode laughing at the rest,

Nodding and shaking of thy spangled crest,

Where women's favors hung like labels down. (2.2.181-6)

To which Lancaster adds

And thereof came it that the fleering Scots,

To England's high disgrace, have made this jig:

"Maids of England, sore may you mourn,

For your lemans you have lost at Bannocksbourn,

With a heave and a ho!

What, weeneth the King of England

So soon to have won Scotland?

With a rumbelow!" (2.2.187-94)

England's shameful defeat at Bannockburn is yet another example of the play's representation of Edward's woefully incompetent rule, but it also figures centrally in the play's anxious inscription of nationhood as England is threatened by internal as well as external forces.

When news arrives of Mortimer Senior's having been 'taken prisoner by the Scots' (2.2.115), a fierce debate between the peers and Edward regarding Mortimer Senior's ransom ensues. This leads to the play's defining archipelagic moment, not to mention one of the most scathing attacks on Edward's rule:

LANCASTER. Look for rebellion; look to be deposed.

Thy garrisons are beaten out of France,

And lame and poor lie groaning at the gates.

The wild O'Neill, with swarms of Irish kerns,

Lives uncontrolled within the English pale.

Unto the walls of York the Scots made road,

And, unresisted, drave away rich spoils.

MORTIMER JR. The haughty Dane commands the narrow seas,

While in the harbor ride thy ships unrigged. (2.2.156-67)

These lines present an England beleaguered from almost all sides, the exception being Wales, in which the play sets one scene and, moreover, which the play presents more favourably 
than the chronicle sources. ${ }^{30}$ Lancaster's reference to the loss of English possessions in France is recorded in the chronicle sources; however, it also functions as an unsettling reminder of the not-too-distant Tudor loss of England's last continental possession, Calais, in 1558. The Scottish assault on York posits an encroaching Scotland, which is reinforced by Lancaster's 'The northern borderers, seeing their houses burnt, / Their wives and children slain, run up and down, / Cursing the name of thee and Gaveston' (2.2.178-80). The 'wild O'Neill' is the most obvious example of Marlowe's conscious anachronism, as one editor of the play notes: 'The printed sources make no mention of the O'Neill who was actually involved in the Irish hostilities of 1315-1318; but the "wild" O'Neills, Turlough Liuneach and Hugh, Earl of Tyrone, were persistently troubling the "Pale" (area of supposedly stable English administration) throughout the 1580s and 1590s' (Marlowe 1994, p. 104). Here, Marlowe seems more indebted to contemporary accounts of the beginnings of what would come to be called the Nine Years War than he is to Holinshed's account of Edward II's reign. ${ }^{31}$ Because Mortimer Junior's reference to the 'haughty Dane' is not upon historical record, Marlowe's addition works to heighten the sense of an England under siege, amplifying the threat that Edward's weak rule poses to the interests of the political nation.

As mentioned, the initial 1594 publication of Marlowe's Edward II was followed by three subsequent early modern editions, published in 1598, 1612 and 1622 . What made this play popular among Elizabethan and Jacobean readers? Perry cogently argues that later editions of Edward II, especially the 1612 and 1622 publications, had everything to do with the cultural and political unease produced by the favouritism rampant in King James VI and I's court. ${ }^{32}$ I would add that the play's republican reimaginings also appealed to its English readers. The play's endorsement of elective monarchy, for instance, can be read as anticipating the dissident voices of select MPs in the 1614 English Parliament who 'dared to argue that James was in fact a king not only "by blood" but also by election "because in passing from Scotland to England he was called and to some extent chosen"' (Doran and Kewes 2014, p. 12). Furthermore, given James's desire to unify Great Britain, and given the fierce parliamentary resistance to James's desired Anglo-Scottish union, we should not overlook the ways in which the archipelagic angles in Marlowe's 'English' history play would have interested Jacobean readers, especially those English MPs who favoured an incorporating union with Scotland. Marlowe may have foreseen James's accession to the English throne, but he could not have predicted the debates on Anglo-Scottish union, the divine right of kings, the ancient constitution, parliamentary prerogative and national sovereignty that surfaced in the early years of James's English reign, when England's Scottish monarch alienated himself from his English Parliament as well as many of his English subjects. His play, not surprisingly, proved to be just as topical for Jacobean readers as it was for Elizabethan readers. ${ }^{33}$

Funding: This research received no external funding.

Conflicts of Interest: The author declares no conflict of interest.

\section{Notes}

1 'In the work of Munday, Chettle, Heywood, Dekker, and their collaborators, common people and their upperclass champions occupy the central place' (Helgerson 1992, p. 234).

2 'Marlowe's republican authorship', Patrick Cheney argues, 'does not show a patriotic political program' (Cheney 2006, p. 43). In this essay I take issue with this statement.

3 Unless noted otherwise, all subsequent references are to this text and will be given as (act.scene.line(s)).

When citing Holinshed's Chronicles, I follow The Oxford Handbook of Holinshed's Chronicle's referencing system.

Of the play's five uses of 'tyrant' and related words ('tyrannize' and 'tyrannous'), the first three are directed at Edward II, the last two, spoken by Edward, are directed at Mortimer Junior.

6 According to Holinshed's Chronicles, Edward 'made [Gaveston] ruler of Ireland as his deputie there' (Holinshed 1587, III, p. 320). 
Significantly, 'nation' (4.3.35) is the word of a Frenchman, Levune, although it is spoken by Spencer Junior whilst reading from Levune's letter.

8 Marlowe's main source for Edward II, Holinshed's Chronicles, also uses 'realm' most frequently to refer to 'England', followed by 'the land' and 'commonwealth'. 'Country' and 'kingdom' are used less frequently, and 'the English nation' just once.

9 'Kingship', Anderson notes, 'organizes everything around a high center. Its legitimacy derives from divinity, not from populations, who, after all, are subjects, not citizens' (Anderson 1991, p. 19).

Perry describes Smith's England as 'something like a monarchical republic ... a state in which the absolute powers accorded to the king in many areas coexist with and are balanced by parliament and customary law' (Perry 2006, p. 186). See also McLaren (1999) and for Person's Conference Kewes (2019).

Hadfield describes Marlowe's Edward II as 'a further republican context for Shakespeare's early histories' (Hadfield 2005, p. 105). On Marlowe's contributions to the plays to which scholars commonly refer as 1 Henry VI, 2 Henry VI and 3 Henry VI, see, for example, Burrows and Craig (2017). See also Cadman (2015), who explores republican interrogations of sovereign-subject relations in late Elizabethan and early Jacobean 'closet drama'.

Paulina Kewes cites Hadfield and Cheney as examples of literary critics who 'have strained Collinson's argument in a bid to cast some of Elizabethan England's most illustrious writers, notably Shakespeare and Marlowe, as somehow capable of sustaining those progressive beliefs often uncritically associated with modern liberal democracies' (Kewes 2015, p. 623). Both Hadfield and Cheney, it should be noted, argue that Shakespeare and Marlowe retrieve 'progressive beliefs' from ancient Roman texts and culture.

Hadfield labels Shakespeare's three Henry VI plays and Richard III 'Shakespeare's Pharsalia'. Marlowe, of course, translated the first book of Lucan's Pharsalia, which was published posthumously in 1600, although it is referenced seven years earlier in the Stationers' Register.

On Edward II's reign, see Fryde (1979). Marlowe's Edward II, Fryde suggests, 'has captured the essential atmosphere of [Edward's and the Despenser's] regime perhaps better than any historian has since been able to do' (Fryde 1979, p. 7).

It is interesting that Edward terms Mortimer Junior, whom the play designates 'Protector', rather than Prince Edward as a 'new elected king'.

Paulina Kewes claims that Edward II 'casts election as unconstitutional and inextricably linked with Catholic resistance theory' (Kewes 2013, p. 503), but she bases this argument on one speech by Edward-'Why should a king be subject to a priest?' (1.4.96) - and therefore neglects the play's fuller articulation of elective monarchy.

The historical Sir William Trussell served as Proctor of Parliament, and played a crucial role in Edward's deposition: see Roy Martin Haines's entry on Trussell in the ODNB ().

'Regiment' is a key word in the play. It first occurs when Edward says to Gaveston 'for but to honor thee / Is Edward pleased with kingly regiment (1.1.163-4), revealing the King's commitment to private over public desire, and its second occurrence-'to cross the seas with [Queen Isabella's] young son, / And step into his father's regiment' (3.3.50-1)—foreshadows Edward's deposition.

Lisa Hopkins's article is a noticeable exception. Furthermore, Hopkins argues that not only Edward II but all of Marlowe's plays have yet to be explored in a larger archipelagic context: 'in the growing push to map the extent of English Renaissance drama's engagement with the ways in which the previously securely separate territories of England, Scotland, Ireland, and Wales were and were not being moulded into a unified and cohesive "Great Britain", relatively little attention has been paid to the plays of Christopher Marlowe' (Hopkins 2010, p. 325).

For a survey of readings of Edward and Gaveston's same-sex relationship as well as an intelligent critical commentary, see Crewe (2009). For an account of King Edward II's reception in the medieval and early modern periods, especially in literary texts and in relation to discourses of sexual transgression, see Heyam (2020). For readings of nationhood in the play that highlight Gaveston's sexuality, see Bianco (2007) and Stanivukovic and Goodwin (2017).

On favouritism and social status, see Siemon (2018) and Stewart (2018).

I am indebted here to the ODNB entry on 'Gaveston, Piers, earl of Cornwall'.

John Stow describes Edward as 'disposed to lightnesse, haunting the company of vile persons, and giuē wholy to the pleasure of the bodye, not regarding to gouerne his common weale by discretion and iustice' (Stow 1580, p. 325).

Edward's 'Fawn not on me, French strumpet' (1.4.145), which he directs to the Queen, is the sole exception.

Similarly, Bianco argues that 'Ireland materialises in the figure of Gaveston, who, as governor of Ireland, comes to embody the dangerousness that Ireland poses to the sanctity of the English nation and to the purity of English national identity' (Bianco 2007, para 4).

Gaveston's use of 'lordly' denotes 'Arrogant, haughty, imperious, disdainful' (OED, adj.3).

The earliest printed version of the play gives 'Britanie' (Marlowe 1594, D3v), a spelling of Britain that also appears in the First Folio-spoken by Iachimo in Cymbeline.

28 Hopkins notes that Edward II 'glances at Ireland, Scotland, and Wales as well as England (Hopkins 2010, p. 337); my point is that the play does much more than glance at these neighbour nations. 
In terms of the play's Anglo-Scottish warfare, the key battle is Bannockburn. The Soldier's reference to having served against the Scot cannot be to Bannockburn, for that battle occurred after Gaveston's return to England from France.

30 I have in mind Mortimer Junior's 'You, Rice ap Howell, / Shall do good service to Her Majesty/Being of countenance in your country here, / To follow these rebellious runagates' (4.6.73-6).

31 Ample space is, however, given over in the chronicle sources to Edward Bruce's military exploits in Ireland during Edward II's reign.

'The central native exemplum of passionate and corrupting favoritism, for Elizabethan and early Stuart writers, is clearly the tale of the reign, deposition, and murder of King Edward II' (Perry 2006, p. 185).

On the magistrate John Newdigate's topical reading of Edward II in the wake of Essex's failed rebellion, see Keenan (2006).

\section{References}

Anderson, Benedict. 1991. Imagined Communities: Reflections on the Origin and Spread of Nationalism, Rev. ed. London: Verso.

Bartels, Emily C. 1993. Spectacles of Strangeness: Imperialism, Alienation, and Marlowe. Philadelphia: University of Pennsylvania Press.

Bianco, Marci. 2007. To Sodomize a Nation: Edward II, Ireland, and the Threat of Penetration. Early Modern Literary Studies. Available online: http:/ / purl.oclc.org/emls/si-16/bianedii.htm (accessed on 19 June 2021).

Brown, Georgia E. 2002. 'Tampering with the Records: Engendering the Political Community and Marlowe's Appropriation of the Past in Edward II. In Marlowe's Empery: Expanding His Critical Contexts. Edited by Sarah Munson Deats and Robert A. Logan. Newark: University of Delaware Press, pp. 164-87.

Burrows, John, and Hugh Craig. 2017. The Joker in the Pack?: Marlowe, Kyd and the Co-authorship of Henry VI, Part 3. In The New Oxford Shakespeare: Authorship Companion. Edited by Gary Taylor and Gabriel Egan. Oxford: Oxford University Press, pp. 194-217.

Cadman, Daniel. 2015. Sovereigns and Subjects in Early Modern Neo-Senecan Drama: Republicanism, Stoicism and Authority. Farnham: Ashgate.

Calhoun, Craig. 1997. Nationalism. Minnesota: University of Minnesota Press.

Cheney, Patrick. 2006. "Defend his freedom' gainst a monarchy": Marlowe's Republican Authorship. In Textual Conversations in the Renaissance: Ethics, Authors, Technologies. Edited by Benedict S. Robinson and Zachary Lesser. London: Routledge, pp. $27-45$.

Cheney, Patrick. 2009. Marlowe's Republican Authorship: Lucan, Liberty, and the Sublime. Basingstoke: Palgrave Macmillan.

Collinson, Patrick. 1990. De Republica Anglorum, or History with the Politics Put Back. Cambridge: Cambridge University Press.

Crawford, Robert. 2014. Bannockburns: Scottish Independence and Literary Imagination, 1314-2014. Edinburgh: University of Edinburgh Press.

Crewe, Jonathan. 2009. Disorderly Love: Sodomy Revisited in Marlowe's Edward II. Criticism 51: 385-99. [CrossRef]

Davies, R. R. 2000. The First English Empire: Power and Identities in the British Isles, 1093-1343. Oxford: Oxford University Press.

Doran, Susan, and Paulina Kewes, eds. 2014. Doubtful and Dangerous: The Question of Succession in Late Elizabethan England. Manchester: Manchester University Press.

Fryde, Natalie. 1979. The Tyranny and Fall of Edward II, 1321-6. Cambridge: Cambridge University Press.

Gill, Roma. 1980. Mortimer's Men. Notes and Queries 27: 159. [CrossRef]

Greenfeld, Liah. 1992. Nationalism: Five Roads to Modernity. Cambridge: Harvard University Press.

Hadfield, Andrew. 2005. Shakespeare and Republicanism. Cambridge: Cambridge University Press.

Helgerson, Richard. 1992. Forms of Nationhood: The Elizabethan Writing of England. Chicago: University of Chicago Press.

Hertel, Ralf. 2014. Staging England in the Elizabethan History Play: Performing National Identity. Farnham: Ashgate.

Heyam, Kit. 2020. The Reputation of Edward II, 1305-1697: A Literary Transformation of History. Amsterdam: Amsterdam University Press. Holinshed, Raphael. 1587. The Firste Volume of the Chronicles of England, Scotlande, and Irelande. London: STC 13569.5.

Hopkins, Lisa. 2010. Englishmen Abroad: Mobility and Nationhood in Dido, Queen of Carthage and Edward II. English 59: 324-48. [CrossRef]

Keenan, Siobhan. 2006. Reading Christopher Marlowe's Edward II: The Example of John Newdigate in 1601. Notes and Queries 53: 452-58. [CrossRef]

Kewes, Paulina. 2013. History Plays and the Royal Succession. In The Oxford Handbook of Holinshed's Chronicles. Edited by Paulina Kewes, Ian W. Archer and Felicity Heal. Oxford: Oxford University Press, pp. 493-509.

Kewes, Paulina. 2015. “A mere historian": Patrick Collinson and the Study of Literature. History 100: 609-25. [CrossRef]

Kewes, Paulina. 2019. "The idol of state innovators and republicans": Robert Persons's A Conference About the Next Succession (1594/5). In Stuart Succession Literature: Moments and Transformations. Edited by Paulina Kewes and Andrew McRae. Oxford: Oxford University Press, pp. 149-85.

Marlowe, Christopher. 1594. The Troublesome Raigne and Lamentable Death of Edward the Second, King of England: With the Tragicall Fall of Proud Mortimer: As It Was Sundrie Times Publiquely Acted in the Honourable Citie of London, by the Right Honourable the Earle of Pembrooke His Seruants. Written by Chri. London: Marlow Gent.

Marlowe, Christopher. 1994. Edward II. Edited by Richard Rowland. Oxford: Clarendon Press.

Marlowe, Christopher. 2002. Edward II. In English Renaissance Drama: A Norton Anthology. Edited by David Bevington, Lars Engle, Katharine Eisaman Maus and Eric Rasmussen. New York: W. W. Norton, pp. 351-420. 
McLaren, Anne. 1999. Reading Sir Thomas Smith's De Republica Anglorum as Protestant Apologetic. The Historical Journal 42: 911-39. [CrossRef]

O'Neill, Stephen. 1999. Staging Ireland: Representations in Shakespeare and Renaissance Drama. Dublin: Four Courts Press.

ODNB. 2021. Available online: https:/ / www.oxforddnb.com/ (accessed on 12 September 2021).

OED. 2021. Available online: https:/ / www.oed.com/ (accessed on 25 August 2021).

Parks, Joan. 1999. History, Tragedy, and Truth in Christopher Marlowe's Edward II. SEL 39: 275-90.

Perry, Curtis. 2006. Literature and Favoritism in Early Modern England. Cambridge: Cambridge University Press.

Siemon, James. 2018. “Overpeered” and Understated: Conforming Transgressions and Edward II. In Edward II: A Critical Reader. Edited by Kirk Melnikoff. London: Bloomsbury, pp. 145-74.

Stanivukovic, Goran, and Adrian Goodwin. 2017. Gaveston in Ireland: Christopher Marlowe's Edward II and the casting of queer brotherhood. Textual Practice 31: 379-97. [CrossRef]

Stewart, Alan. 2018. Edoüard et Gaverston: New Ways of Looking at an English History Play. In Edward II: A Critical Reader. Edited by Kirk Melnikoff. London: Bloomsbury, pp. 97-118.

Stow, John. 1580. The Chronicles of England, from Brute vnto this Present Yeare of Christ. London: Iohn Stow citizen of London. 